\title{
THE ESSENCE AND STRUCTURE OF KEY COMPETENCIES OF FUTURE SKILLED SEWING WORKERS
}

\author{
Halyna Odnoroh, \\ Postgraduate Student of the Institute for Vocational Education of the National Academy of Pedagogical Sciences of Ukraine \\ http://orcid.org/0000-0003-4498-0816 \\ e-mail: RGV.20.04@gmail.com
}

\begin{abstract}
The article presents key competencies as a complex of important qualities of a modern specialist, which are required for successful professional performance, self-realization and full-fledged life of an individual. The relevance of the topic is caused by the rapid growth of requirements for a skilled worker, the interest of modern entrepreneurs in the specialists, who are able to work with information, be creative and think critically, discover optimal solutions, express and defend their own opinion, cooperate and collaborate. Such concepts as "competency" and "key competencies" are specified. The views on key competencies are presented in the context of European and Ukrainian legislation. The article highlights the need to develop those competencies in future skilled workers, which contribute to developing personal potential, promote self-realization, expand employment opportunities and ensure success in a rapidly changing society.

Key competencies of future sewing workers are presented as a system of competencies, which, when combined with professional knowledge, skills and abilities, will allow such workers to achieve positive results in personal and professional life and will ensure an effective interpersonal interaction in the production environment. It is proved that the key and professional competencies of sewing workers are interrelated and should be formed and developed simultaneously. The article justifies the need to develop these qualities in the process of educating future tailors and cutters, whose professional activity is connected with communication with the customer, the choice of a model and material, fittings, detection and elimination of defects, ability to work on several orders simultaneously.

The list of key competencies needed to be formed in future sewing workers is prepared taking into account the functions of tailors and cutters and based on "soft skills" announced at the 48th World Economic Forum in Davos. They include the ability to solve problems comprehensively; creativity; interaction with people; emotional intelligence; ability to express one's own opinion; focus on the customer; ability to quickly switch from one thought to another.
\end{abstract}

Keywords: key competencies, professional competencies, competency-based approach, skilled worker, sewing industry.

Introduction. Under today's conditions, there appears to be a considerable need for an individual who is able to adapt to the changing nature of a modern socioeconomic environment. The traditional system of education aimed at acquiring knowledge and skills does not correspond to the modern social order, which requires independent, initiative and responsible members of society, who should be willing to fulfil social, production and economic tasks (Yershova, 2015, Kravets, 2014).
The rapid development of globalization processes in society leads to a steady increase in the requirements for a skilled worker. A modern entrepreneur is interested in the worker who is able to think independently, critically and creatively, work with information, discover optimal solutions to overcome current production issues, be sociable (Kravets, 2014, p. 105). A modern individual tends to develop a professional career, which is ensured by a non-standard approach to solving problems, capacity for professional 
adaptation, ability to prove their own opinion, connect to people, work in a team, strive for self-study. Therefore, modern educational institutions should not only transmit knowledge but also form personal qualities in future skilled workers, which they will need for effective professional performance and integration of professional knowledge, skills and abilities, psychological readiness for professional activity, the achievement of professional success and career growth (Romanova, 2009). Thus, it is important to form and develop key competencies in future sewing workers.

The sewing industry requires competent, mobile and competitive workers who meet the level of modern and advanced requirements of this industry. The current problem of vocational education includes updating and improving the content of vocational training and the system of qualifications. Modern employers consider them ineffective since they do not provide objective information about the quality of the acquired knowledge, skills and competencies, which would meet current needs of the labour market (Radkevych, 2000, pp. 151-152).

Materials and methods. Modern models for developing key competencies rely on the principles of competency-based approach. Its essence is rooted in the fact that the main attention is paid to learning outcomes. As a result, the emphasis is placed on the individual's ability to act effectively in various professional and life situations rather than the amount of the acquired information. This is reflected in researches by many Ukrainian and foreign scholars (A. Barannikov, V. Baidenko, V. Bezrukova, N. Bibik, N. Chomsky, M. Holsted, H. Khalazh, A. Khutorskyi, S. Kravets, N. Kuzmina, A. Markova, T. Orji, V. Petruk, O. Pometun, V. Radkevych, J. Raven, O. Semenog, M. Stoart, O. Temniatkin, E. Zeyer, I. Zymniaia et al.). This problem was in particular studied by I. Zymniaia (key competencies as the target-based ground of competency-based approach in education), A. Khutorskyi (key competencies as a personalityoriented paradigm of education), N. Bibik (a reflexive analysis on the application of competency-based approach), V. Radkevych (the importance of professional and key competencies in professional education), S. Kravets (forming key competencies in future restaurant specialists).

Theoretical analysis of scientific works was employed to prove the need to study the problem of forming key competencies in future sewing workers and thoroughly explore the content and structure of their key competencies.

The research aims to study and analyze the essence and structure of key competencies of future sewing workers.

Results and discussions. The English psychologist J. Raven (1999) defines competency "as a specific ability to effectively perform concrete actions in a subject area, including narrow subject knowledge, a particular type of subject skills, ways of thinking, understanding of responsibility for one's actions". O. Pometun (Bibik et al., 2004, p. 18) notes that competency is "an integrated combination of knowledge, abilities and skills that allow one to effectively solve certain problems and tasks in a particular activity". According to H. Selevko (2004, p. 139), competency is an integral quality of an individual, which manifests itself in their overall ability and readiness for activity based on the knowledge and experience acquired during learning and socialization and focused on independent and successful participation in the activity. K. Dmytrenko (2018, p.6) defines competency as a quality acquired by "living situations" and "reflecting experience" and expands it into components (knowledge, skills, abilities, patterns of behaviour, efforts).

The Law of Ukraine "On Higher Education" (2014) defines competency as a dynamic combination of knowledge, abilities and practical skills, ways of thinking, professional, ideological and civic qualities, moral and ethical values, which "determines the ability of an individual to successfully conduct professional and further educational activities and is the result of studying at a certain level of higher education".

This leads to a conclusion that competency is an ability and willingness of an individual to conduct certain professional activities based on knowledge and experience and solve difficult problems by mobilizing their own psychological resources.

According to the Concept of the New Ukrainian School, key competencies are communication in the national language (and mother tongue if different); communication in foreign languages; mathematical literacy; competencies in sciences and technologies; ICT and digital competencies; lifelong learning skill; social and civil competencies; sense of entrepreneurship; cultural awareness; environmental awareness and healthy lifestyles (Ministerstvo osvity i nauky Ukrainy, 2016, pp. 11-12).

The European Commission's working document "Key Competences for Lifelong Learning" defines the term "competence" as a combination of skills, knowledge, abilities and attitudes to learning and gaining practical experience (Key Competences for Lifelong Learning, 2018). In addition, on January 17, 2018, the European Parliament and the Council of the European Union approved the framework programme for updated key competences for lifelong learning, which includes literacy; linguistic competence; mathematical competence and competence in sciences, technologies and engineering; digital competence; personal, social and educational competence; civil competence; entrepreneurial competence; cultural 
awareness and self-expression (life skills-based education).

Practice shows that only professional skills are not enough to achieve professional success. An individual achieves professional realization if they have not only hard skills but also soft and digital skills (Yershova, 2018, p. 165). Top 10 soft skills needed to achieve professional success and career growth were announced at the 48th World Economic Forum in Davos. They include ability to solve problems comprehensively; critical thinking; creativity; ability to manage people; interaction with people; emotional intelligence; ability to express one's own opinion; focus on the customer; ability to negotiate; flexible brain (ability to quickly switch from one thought to another). In 2019, at the World Economic Forum in Davos, they highlighted the need for significant educational changes related to the Fourth Industrial Revolution, the need to focus on the ways and forms of learning. They include "studying computer science with an emphasis on teamwork and creativity, learning through games that develop critical thinking, support of students' initiative outside the curriculum" (Korniienko, 2019). Thus, the main attention is paid to the need to develop key competencies. These competencies are necessary for life activity, development and growth of personal potential, selfrealization, expansion of employment opportunities, success in a fast-changing society. These competences begin to form from an early age and develop in the process of learning throughout their lives.

Therefore, the modernization of Ukrainian education is aimed at the need to form key competencies at school. Given the existing trends in education and training, the European Commission's Key Competences for Lifelong Learning, the results of the World Economic Forum in Davos and the impact of technologies on the labour market, one can conclude that key competencies should be formed and developed during the educational process in the institutions of general, professional (vocational) and higher education.

Both rapid development of the fashion industry and dynamic enhancement of sewing equipment and technology highlight the need for competent sewing workers, who possess knowledge of related professions. They should possess profound professional competencies. Indeed, they should be able to define the characteristics of figure, take measurements, choose a model of clothing in accordance with the customer's figure, choose materials based on their measurements and in accordance with a type and model of clothing, create a design, model properly, make a product of high quality, create a positive emotional atmosphere for the customer.
In order to achieve high results, it is important to take into account each stage of creating clothing. The main sources of acquiring these competencies include vocational training and personal experience. One cannot become a famous designer, start one's own business or promote one's own brand without acquiring a trade job, without gradually mastering all aspects of professional craftsmanship, namely a sewer, a tailor and a cutter.

However, O. Dubnytska (2013, p. 5) believes that the process of acquiring key competencies allows sewing workers to achieve results in their personal and professional lives, ensuring "effective interpersonal interaction in the production environment". In other words, key competencies, apart from purely professional knowledge and skills, also include such qualities as initiative, cooperation, sociability, ability to work in teams, evaluate and analyze problems, use the obtained information and choose the most optimal solutions.

O. Dubnytska (2013, p. 6), studying competencybased and inherent approaches to forming vocational training of sewing workers, proves the close connection between professional and key competencies. The researcher indicates that this approach "directs professional activity towards forming and recreating social requirements of society", while the level of professionalism "generates the necessary creative attitude towards work, ability to make decisions and evaluate them".

Successful professional activity is an integral part of a full-fledged life and self-realization of an individual. It is ensured through forming and developing key and professional competencies. The functions of sewing workers at enterprises are aimed at solving specific problems, namely making sewing products, performing one or more technological operations. This type of work requires that tailors should be attentive to details, possess relevant motor skills, show emotional restraint and stability in emergency situations, possess tactile sensitivity, understand the interlinks between their knowledge, be ready for monotonous activity, be able to work effectively as a subordinate, organize their work and be responsible for the results, work both independently and in a team, show integrity and discipline, think critically and analytically.

In the field of consumer services, the integral part of tailors' and cutters' duties, who work in workshops and tailoring houses with individual orders, includes communication with customers when placing an order, discussing and choosing a model, selecting materials, taking measurements, identifying and removing defects. Therefore, the representatives of these professions should possess the following welldeveloped qualities: sociability, interaction with 
people, ability to express their own opinions and make decisions, listening skills, emotional self-control, creative and critical thinking, ability to focus, etc. Sewing workers, especially cutters, should also develop artistic skills, a sense of taste and style, a sense of fashion and strive for self-development since cutters in fashion and tailoring houses also perform a role of a designer.

Consequently, one can conclude that the main components of key competencies of future sewing workers should be the ability to solve problems comprehensively; creativity; interaction with people; emotional intelligence; ability to express one's own opinion; focus on the customer; ability to quickly switch from one thought to another. The ability to solve problems comprehensively determines the conscious attitude of future cutters towards the entire list of production tasks and understanding of the most rational algorithm for their solving; ability to identify and eliminate the causes of production situations rather than their consequences. Thus, cutters' ability to solve problems comprehensively should be formed based on a systematic and interdisciplinary approach to organizing their vocational training. This competency is important at the stage of placing an order: understanding the characteristics of the customer's figure, taking measurements, choosing models and materials. It is closely intertwined with professional knowledge, skills and abilities. Creativity is an ability to think innovatively, creatively develop one's own experience, apply innovative approaches to problemsolving. Workers specializing in the sewing industry and, in particular, consumer services should be interested in the development of fashion trends, study design techniques, develop spatial thinking, model complex structures, explore and select small operating methods for processing materials.

Interaction with people determines the establishment of relationships at different levels, creating a common field of activity for solving problems. Emotional intelligence is an ability to recognize and understand the intentions of others, control one's own emotions and influence the emotions of others. Being able to express one's own opinion implies the courage to make independent decisions and readiness to answer for their consequences. The focus on customer characterizes the interaction with others and the process of solving people's problems based on the understanding of their values and needs. Since interaction with people, emotional intelligence, ability to express one's own opinion and focus on the interests and needs of customers form the basis of communication skills, the current research suggests that they should be combined into a group of "key communicative competences".

Being able to quickly switch from one thought to another involves contemplating several ideas and simultaneous solving of several production tasks. This is due to the fact that at the enterprises of both mass production and individual order, sewing workers face the need to simultaneously cut and assemble several different types and patterns of clothing. Therefore, such competency is extremely important.

Conclusions. Thus, key competencies of future sewing workers form a system of competencies, which, when combined with professional knowledge, skills and abilities, will allow such workers to achieve positive results in personal and professional life and will ensure an effective interpersonal interaction in the production environment. Key and professional competencies of sewing workers are interrelated and should be formed and developed simultaneously. Successful professional activity depends directly on the level of theoretical and practical knowledge, abilities, skills and experience, as well as the ability to effectively act in various professional and life situations.

Therefore, key competencies of future sewing workers are closely related to professional knowledge, abilities and skills. The processes of their forming and developing is a thorny issue of vocational education, which affects the success of the relevant professional activity, the quality of the service sector and the competitiveness of the enterprise. Therefore, further research should be aimed at studying the peculiarities of forming key competencies in future sewing workers in vocational education institutions.

\section{List of references}

Бібік, Н., Ващенко, Л, Локшина, О., Оварчук, О., Паращенко, Л., Пометун, О., Савченко, О. та Трубачева, С., 2004. Компетентнісний підхід у сучасній освіті: світовий досвід та украӥнські перспективи. Київ: К.І.С.

Верховна рада України, 2014. Закон України "Про вищу освіту", № 37-38. [online] [Останнє оновлення 25 Липень 2018] Доступно: <http://zakon3.rada.gov.ua/laws/show/1556-18>. [Дата звернення 15 Березень 2019].

Дмитренко, К., Коновалова, М., Семиволос, О. та Бекетова, С. 2018. Загальні форми навчання-новий підхід: розвиваємо ключові компетентності: метод. посіб. Харків: ВГ "Основа".

Дубницька, О. М., 2013. Компетентністно-інегративний підхід до формування професійної підготовки фахівців швейного профілю. Нові технологї̈ навчання: наук.-метод. зб. (Інститут інноваційних технологій $i$ змісту освіти Міністерства освіти і науки Украӥни, академія міжнародного співробітництва з креативної педагогіки), 76, с. 246-250.

Єршова, Л., 2015. Формування референтної особистості як проблема освітньої практики сучасної України. Вісник Черкаського національного університету. Педагогічні науки, 6 (339), с. 119-124. 
Єршова, Л., 2018. Трансформація системи цінностей учнівської і студентської молоді в контексті реформування вітчизняної професійної освіти. Науковий вісник Інституту професійно-технічної освіти НАПН Украӥни. Професійна педагогіка, 16, с. 162-168.

Корнієнко, Я., 2019. Давос-2019: головні меседжі Всесвітнього економічного форуму. Украӥнська правда. Економічна правда. [online] Доступно: <https://www.epravda.com.ua/publications/2019/01/27/644694/> [Дата 3вернення 8 Травень 2019].

Кравець, С., 2014. Формування ключових компетентностей у процесі професійної підготовки майбутніх фахівців ресторанного сервісу: результати педагогічного експерименту. Професійна освіта: проблеми і перспективи, 6, с. $105-110$.

Міністерство освіти і науки України, 2016. Концептуальні засади реформування середньої освіти. Нова українська школа. [online] Доступно: <https://mon.gov.ua/storage/app/media/zagalna\%20serednya/nova-ukrainska-shkolacompressed.pdf $>$ [Дата звернення 9 Квітень 2019].

Освіта на основі життєвих навичок. Адвокаційний модуль для керівних кадрів, 2019. Ключові компетентності для навчання протягом життя. [online] Доступно: <http://dlse.multycourse.com.ua/ua/page/15/53> [Дата звернення 24 Березень 2019]. Центр.

Равен, Дж., 1999. Педагогическое тестирование: проблемы, заблуждения, перспективы. Москва: Когито-

Радкевич, В. О., 2000. Моделювання одягу: підручник для учнів ПТНЗ. Київ: Вища школа.

Романова, Г.М., 2009. Психолого-педагогічна підготовка як чинник професійної самореалізації викладачів економічного університету. Вісник Львівського університету, 3(25), с. 167-175.

Селевко, Г., 2004. Компетентности и их классификация. Народное образование, 4, с. 138-143.

Key Competences for Lifelong Learning. Commission staff working document, 2018. [online] Доступно: <https:// eur-lex.europa.eu/legal-content/EN/TXT/PDF/?uri=CELEX:52018SC0014\&from=EN> [Дата звернення 8 Травень 2019].

\section{Translated \& Transliterated}

Bibik, N., Vashchenko, L, Lokshyna, O., Ovarchuk, O., Parashchenko, L., Pometun, O., Savchenko, O. ta Trubacheva, S., 2004. Kompetentnisnyi pidkhid u suchasnii osviti: svitovyi dosvid ta ukrainski perspektyvy [Competency-based approach in modern education: world experience and Ukrainian prospects]. Kyiv: K.I.S, [in Ukrainian].

Verkhovna rada Ukrainy [Supreme Council of Ukraine], 2014. Zakon Ukrainy "Pro vyshchu osvitu", [The Law of Ukraine "On Higher Education"] № 37-38. [online] [Ostannie onovlennia 25 Lypen 2018] Dostupno: <http:// zakon3.rada.gov.ua/laws/show/1556-18>. [Data zvernennia 15 Berezen 2019], [in Ukrainian].

Dmytrenko, K., Konovalova, M., Semyvolos, O. ta Beketova, S., 2018. Zahalni formy navchannia - novyi pidkhid: rozvyvaiemo kliuchovi kompetentnosti: metod. posib [General forms of learning - a new approach: developing key competencies: a manual]. Kharkiv: VH "Osnova", [in Ukrainian].

Dubnytska, O. M., 2013. Kompetentnistno-inehratyvnyi pidkhid do formuvannia profesiinoi pidhotovky fakhivtsiv shveinoho profiliu [Competency-based approach to forming vocational training of sewing workers]. Novi tekhnolohii navchannia: nauk.-metod. zb. [New learning technologies: a scientific and methodical collection] (Instytut innovatsiinykh tekhnolohii i zmistu osvity Ministerstva osvity i nauky Ukrainy, akademiia mizhnarodnoho spivrobitnytstva z kreatyvnoi pedahohiky) [The Institute for Innovative Technologies and Education Content of the Ministry of Education and Science of Ukraine, The Academy of International Collaboration in Creative Pedagogy], 76, s. 246-250, [in Ukrainian].

Yershova, L., 2015. Formuvannia referentnoi osobystosti yak problema osvitnoi praktyky suchasnoi Ukrainy [Forming a reference person as a problem of educational practice in the modern Ukraine]. Visnyk Cherkaskoho natsionalnoho universytetu. Pedahohichni nauky [The Journal of Cherkasy National University. Pedagogy], 6 (339), s. 119-124, [in Ukrainian].

Yershova, L., 2018. Transformatsiia systemy tsinnostei uchnivskoi i studentskoi molodi v konteksti reformuvannia vitchyznianoi profesiinoi osvity [Transforming a system of values for pupils and students in the context of updating the Ukrainian professional education]. Naukovyi visnyk Instytutu profesiino-tekhnichnoi osvity NAPS of Ukraine. Profesiina pedahohika [Scientific herald of the Institute of vocational education and training of NAES of Ukraine. Professional Pedagogy], 16, s. 162-168, [in Ukrainian].

Korniienko, Ya., 2019. Davos-2019: holovni mesedzhi Vsesvitnoho ekonomichnoho forumu [Davos-2019: the main messages of the World Economic Forum]. Ukrainska pravda. Ekonomichna pravda [Ukrainian Truth. Economic Truth]. [online] Dostupno: <https://www.epravda.com.ua/publications/2019/01/27/644694/> [Data zvernennia 8 Traven 2019], [in Ukrainian].

Kravets, S., 2014. Formuvannia kliuchovykh kompetentnostei u protsesi profesiinoi pidhotovky maibutnikh fakhivtsiv restorannoho servisu: rezultaty pedahohichnoho eksperymentu [Forming key competences during vocational training of restaurant specialists: the results of pedagogical experiment]. Profesiina osvita: problemy i perspektyvy [Professional education: problems and prospects], 6, s. 105-110, [in Ukrainian].

Ministerstvo osvity i nauky Ukrainy [The Ministry of Education and Science of Ukraine], 2016. Kontseptualni zasady reformuvannia serednoi osvity. Nova ukrainska shkola [Conceptual principles of updating secondary education: the New Ukrainian School]. [online] Dostupno: $<$ https://mon.gov.ua/storage/app/media/zagalna\%20serednya/nova-ukrainskashkola-compressed.pdf> [Data zvernennia 9 Kviten 2019], [in Ukrainian].

Osvita na osnovi zhyttievykh navychok. Advokatsiinyi modul dlia kerivnykh kadriv [Education based on life skills. The advocacy module for management staff], 2019. Kliuchovi kompetentnosti dlia navchannia protiahom zhyttia [Key competencies for lifelong learning]. [online] Dostupno: $<$ http://dlse.multycourse.com.ua/ua/page/15/53> [Data zvernennia 24 Berezen 2019], [in Ukrainian]. 
Raven, Dzh., 1999. Pedagogicheskoe testirovanie: problemyi, zabluzhdeniya, perspektivyi [Pedagogical testing: problems, errors, prospects]. Moskva: Kogito-Tsentr, [in Ukrainian].

Radkevych, V. O. 2000. Modeliuvannia odiahu: pidruchnyk dlia uchniv PTNZ [Modelling clothes: a textbook for vocational education students]. Kyiv: Vyshcha shkola, [in Ukrainian].

Romanova, H.M., 2009. Psykholoho-pedahohichna pidhotovka yak chynnyk profesiinoi samorealizatsii vykladachiv ekonomichnoho universytetu [Psychopedagogical training as a factor in professional self-realization of lecturers at economic universities]. Visnyk Lvivskoho universytetu [The Journal of Lviv University], 3(25), s. 167-175, [in Ukrainian].

Selevko, G., 2004. Kompetentnosti i ih klassifikatsiya [Competencies and their classification]. Narodnoe obrazovanie [National education], 4, s. 138-143, [in Ukrainian].

Key Competences for Lifelong Learning. Commission staff working document, 2018. [online] Dostupno: $<\mathrm{https://eur-}$ lex.europa.eu/legal-content/EN/TXT/PDF/?uri=CELEX:52018SC0014\&from=EN $>$ [Data zvernennia 8 Traven 2019], [in English].

УДК 377.3:687]:005.336.2-027.561

\section{Суть і структура ключових компетентностей майбутніх кваліфікованих робітників швейного профілю}

\section{Галина Однорог,}

аспірантка,

Institute of Vocational Education and Training of NAES of Ukraine

Реферат. Ключові компетентності представлені в статті як комплекс важливих якостей сучасного фахівця, потрібних для успішної професійної діяльності, самореалізації та повноцінного життя особистості. Актуальність даної теми зумовлюється стрімким зростанням вимог до кваліфікованого робітника, зацікавленістю сучасних підприємців у спеціалістах, які вміють працювати з інформацією, володіють творчим та критичним мисленням, знаходять оптимальні рішення, вміють висловлювати та відстоювати власну думку, комунікабельні. Уточнено суть понять "компетентність" і "ключові компетентності". Представлений погляд на ключові компетентності зі сторони європейського та вітчизняного законодавства. Наголошується на необхідності формувати дані компетентності в майбутніх кваліфікованих робітників, що сприяють розвитку особистого потенціалу, самореалізації, розширенню можливостей працевлаштування, успіху в швидкозмінному суспільстві.

Ключові компетентності майбутніх фахівців швейного профілю представлено як систему компетентностей, що в сукупності з професійними знаннями, вміннями та навичками, дасть змогу робітнику даної галузі здобути позитивні результати в особистому і професійному житті та забезпечить ефективну міжособистісну взаємодію в умовах виробництва. Доведено, що ключові та професійні компетентності фахівців швейного напряму взаємопов'язані та повинні формуватися й розвиватися паралельно. Обгрунтовано необхідність розвитку цих якостей у процесі підготовки майбутніх кравців і закрійників, професійна діяльність яких пов'язана зі спілкуванням із замовником, вибором моделі та матеріалу, проведенням примірок, виявленням та усуненням дефектів посадки, здатністю працювати паралельно з декількома замовленнями.

Керуючись функціями кравців та закрійників, взявши за основу "soft skills", озвучених на 48-му Всесвітньому економічному форумі в Давосі, подано перелік ключових компетентностей, які необхідно формувати в майбутньому робітникові даної професії: комплексне розв'язання проблеми; креативність; взаємодія з людьми; емоційний інтелект; уміння формувати власну думку; орієнтація на клієнта; вміння швидко переключатися з однієї думки на іншу.

Ключові слова: ключові компетентності, професійні компетентності, компетентнісний підхід, кваліфікований робітник, швейна галузь. 